Олег БАДАЛОВ

https://orcid. org/0000-0002-2706-1458

\title{
ДІЯЛЬНІСТЬ ЧЕРНІГІВСЬКОГО ВІДДІЛУ «СОЮЗУ УКРАЇНОК» У КОНТЕКСТІ НАЦІОНАЛЬНО-КУЛЬТУРНОГО ВІДРОДЖЕННЯ ЧЕРНІГІВЩИНИ КІНЦЯ ХХ - ПОЧАТКУ ХХІ СТОЛІТЬ
}

У статті досліджено діяльність Чернігівського відділу «Союзу Украӥнок» у контексті розвитку українського гуманітарного простору Чернігівщини. Вивчена діяльність $i$ з'ясовано внесок у національний культурний рух 1990-2014 рр. однієї з ключових постатей мистецького жстття регіону заслуженої артистки Украӥни Р. Решетнюк як голови Чернігівського відділу «Союзу Українок».

Ключові слова: національна культура, демократичний жіночий рух, Чернігівський регіон, «Союз Українок», Р. Решетнюк.

The article investigates the activity of the first democratic women's organization of the border of the $20^{\text {th }}-21^{\text {st }}$ centuries in the Left-Bank Ukraine. Chernihiv Branch of the "Ukrainian Women's Union» analyzed the main directions of its activity in the context of the processes of Ukraine independence renaissance, the development of the Ukrainian humanitarian space of Chernihiv region. The contribution of the leading figure of the artistic life of the region $R$. Reshetnyuk as the head of the Chernihiv Branch of the "Ukrainian Women's Union» in the national cultural movement of 1990-2014 has been clarified.

Keywords: national culture, women's democratic movement, Chernihiv Region, "Ukrainian Women's Union», R. Reshetnyuk.

В статье исследована деятельность Черниговского отдела «Союза Украинок» в контексте развития украинского гуманитарного пространства Черниговщины. Изучена деятельность и обобщен вклад в национальное культурное движение 1990-2014 г2., осуществлённый одной из ключевых фигур культурной жизни региона, заслуженной артисткой Украины Р. Решетнюк как главой Черниговского отдела «Союза Украинок».

Ключевые слова: национальная культура, демократическое женское движение, Черниговский регион, «Союз Украинок», Р. Решетнюк.

Постановка проблеми. Кінець 80-х - початок 90-х рр. ХX ст. в Україні означився піднесенням національно-культурного руху, обумовленого демократизацією суспільства. Серед багатьох громадських організацій, що почали діяти у той час, значний внесок у розвиток українського гуманітарного простору здійснив «Союз Українок» (далі - СУ). Відомо, що СУ був утворений у 1921 р. на Львівському з'їзді, що зібрав «делегаток від різних жіночих організацій Галичини, Волині, Буковини, а також з Відня, Праги та Варшави» $[5,4]$. На західноукраїнських землях СУ припинив своє існування після їх приєднання до УРСР, але продовжив діяльність у діаспорі. На- передодні здобуття незалежності у 1989 р. було відновлено СУ у Львові. Дуже швидко відділи організації виникли в усіх регіонах України. Їх появу можна розглядати як суспільну відповідь на бездіяльність Комітету радянських жінок, що був «єдиним виразником проблем жіноцтва і покірно дивився на найстрашніший злочин тоталітарної системи - Чорнобиль. Мовчав, коли наші діти, оголені під стронцієвим сонцем, ішли у смертельному танку перед трибуною можновладців; закликали до засудження ОУН і УПА, забувши про осудження дій Комуністичної партії» $[6,9]$. Першою у Лівобережній Україні демократичною жіночою організацією став Чернігівський відділ 
«Союзу Українок» (далі - ЧВСУ), заснований у 1990 р. Багатогранна діяльність відділу, якому належить пріоритетна роль у відновленні національного гуманітарного простору Чернігівщини, ще не стала предметом вивчення культурологів і мистецтвознавців, що обумовлює актуальність теми дослідження.

Аналіз досліджень $\boldsymbol{i}$ публікацій. Грунтовне вивчення жіночого руху України порубіжжя XXXXI ст. здійснено Я. Фрондзей [17]; організаційні форми буття «Союзу Українок» у діаспорі дослідили Н. Даниленко, Л. Довгаль [9; 11]; значення жіночого руху у процесах українського державотворення кінця XX ст. висвітлено Н. Дармограй, А. Стахневич, О. Ярош $[10 ; 16 ; 19]$. Регіональна специфіка діяльності «Союзу Українок» представлена переважно у працях, присвячених соціокультурному життю західноукраїнських земель до кінця 1930-х pp. [12; 15]. Особливості появи і функціонування «Союзу Українок» у Лівобережній Україні, зокрема на Чернігівщині, не стали предметом вивчення, що обумовлює наукову новизну обраної теми дослідження.

Mema cmammi - 3'ясування внеску Чернігівського відділу «Союзу Українок» у процес національно-культурного відродження Чернігівщини.

Виклад основного матеріалу. Своєю появою Чернігівський відділ «Союз Українок» завдячує заслуженій артистці України Раїсі Іванівні Решетнюк (1948-2014). Випускниця театрознавчого факультету Державного інституту театрального мистецтва УРСР ім. І. Карпенка-Карого, артистка Чернігівської обласної філармонії, співзасновниця Чернігівської міської «Просвіти», членкиня Конгресу українських націоналістів, вона була однією 3 провідних учасників «буремних подій становлення української державності 1989-1992 років» $[8,206]$. Перебуваючи влітку 1990 р. на гастролях у канадській провінції Альберти, Р. Решетнюк від місцевих українок дізналася про найавторитетнішу громадську організацію «Союз Українок» та iii велику роль у національно-культурному житті материкової України у період між двома світовими війнами й українців діаспори у другій половині XX ст. Після повернення з Канади у липні 1990 р. Р. Решетнюк провела творчу зустріч 3 містянами, на якій розповіла про свої виступи, життя канадських українців і діяльність «Союзу Українок», представила присутнім відеофільм про Голодомор, який отримала від директора Канадського інституту українських студій Б. Кравченка. Наприкінці зустрічі Р. Решетнюк звернулася до присутніх жінок з пропозицією створити
Чернігівський відділ «Союзу Українок». Стати союзянками дали згоду десять чернігівок, серед яких були представниці родин політичного в'язня Л. Лук'яненка та письменника М. Коцюбинського $[18,209]$. 3 часу заснування ЧВСУ активно включився у відродження Української Православної церкви Київського патріархату (далі - УПЦ КП) як однісї зі складових національної самосвідомості й культури. Чернігівські союзянки були серед тих, хто ініціював відновлення богослужінь у храмі Святої Великомучениці Параскеви-П'ятниці XII ст., яка довгі роки мала статус музейної установи. За згадкою учасників молитовного стояння, перші літургії відбувалися під замкненими дверима церкви $[7,64]$. Переконавшись у невідворотності прагнень національно свідомих українців мати свою церкву, обласна влада передала храм УПЦ КП. При освяченні храму, що став кафедральним собором новоутвореної єпархії, голові ЧВСУ Р. Решетнюк було доручено нести ікону св. Параскеви у хресній ході, що засвідчило вагомість внеску союзянок у відновлення українського православного церковного руху Чернігівщини.

Важливою складовою просвітницької роботи ЧВСУ було відродження й пропагування народних звичаїв. Ще до появи ЧВСУ Р. Решетнюк ініціювала проведення у Чернігові у 1989 р. свята Івана Купала, яке зібрало фольклорні колективи 3 усієї області, засвідчивши суспільну зацікавленість у поверненні до традиційної народної культури. Членкині ЧВСУ здійснювали фольклорні експедиції, де збирали матеріали, свідчення, спогади про стародавні звичаї та обряди, працювали у бібліотеках і архівах. Для популяризації народної обрядовості серед широкої аудиторії ЧВСУ утворив Обрядовий співочий гурт, де «не лише співали, пританцьовували, словом і мелодією розважали й тішили людей, а ще й по-мистецьки просто, вибагливо та дохідливо відтворили не одну звичаєво-обрядову сцену $<\ldots .>$, що сповнені і глибокого повчального змісту, і високої народної моралі» [14, 4]. Впродовж 1990-2014 pр. ЧВСУ представляв чернігівцям народні й християнські свята Івана Купала, Трійці, «Обливаний понеділок», «Водіння Куста», Покрови, святого Миколая, Маланки й Василя, Калити, Колодія, Різдвяний вертеп і Великодні забави тощо.

3 обрядовими дійствами союзянки відвідували навчальні заклади, зокрема, «здійснили десант до учнів Чорнобильської зони — в Карпилівську середню школу та Остерський Будинок школяра. Діти побачили тоді обряд свята Миколая - захисника дітей, отримали подарунки, сироти - грошову до- 
помогу» $[18,210]$. Окрім народних пісень, Обрядовий гурт виконував стрілецькі пісні та пісні часів УПА, «у цьому колективі народжуються і нові пісні, твориться нова українська душа» $[18,210]$.

31991 р. ЧВСУ організовував загальноміські святкування Дня Матері, що на державному рівні було визнано лише у 1999 р. Ці заходи ЧВСУ набули міжнародного розголосу: у 1996 р. їх було висвітлено у часописові «Союзу Українок» Америки «Our Life»: «відбулося величаве Свято Матері в Чернігові < . .> Ініціатором свята була Раїса Решетнюк, член міської Ради та голова "Союзу Українок" Чернігова. Вона провела підготовку до свята серед державних та суспільних організацій міста і околиць, наголошуючи, чим воно відрізняється від тих свят, до яких населення України звикло. Підготовка повністю вдалася» $[2,13]$.

Провідним напрямом діяльності ЧВСУ стало повернення із забуття та популяризації у регіоні імені й творчого спадку С. Русової - уродженки Чернігівщини, однієї з провідних постатей національно-визвольних змагань України, видатної представниці всесвітнього українського жіночого руху. Наприкінці літа 1991 р. на координаційній раді «Союзу Українок» у Києві перед ЧВСУ було поставлено завдання забезпечити умови для візиту нащадків С. Русової на Чернігівщину та сприяти проведенню там урочистостей з нагоди 135-річчя від дня народження видатної землячки. 30 вересня 1991 р. до Олешні прибули з США, Канади, Росії, Чехії члени родини С. Русової, артисти обласної філармонії, посадовці, науковці 3 Києва, Чернігова, Ніжина. Відбулася потужна мистецька акція «Софіїн день», в ході якої було встановлено й урочисто відкрито пам'ятний знак діячці. Згадуючи візит в Україну, онука С. Русової Н. Ліндфорс-Михалевич зазначала: «були ми в Чернігові, Ріпках і в селі Олешні, в нашому родовому обійсті. <..> Союзянки наші молодці! Дуже гарно все зорганізували» [3, 10].

Під час проведення урочистостей у Олешні була висловлена думка про присвоєння імені С. Русової місцевій загальноосвітній школі, що згодом спричинило «жорстке й безкомпромісне протистояння $<\ldots>$ реакційний опір місцевої влади, інтелігенції та деяких громадян Олешні» [13, 7]. Рух за присвоєння Олешнянській школі імені С. Русової очолила Р. Решетнюк - «невтомний двигун Чернігівського Союзу Українок» $[1,13]$. Для проведення серед селян роз'яснювальної роботи про С. Русову ЧВСУ 2став здійснювати поїздки до Олешні з обрядовими дійствами, українськими мистецькими програмами, лекціями про життя С. Русової, дарували видання іï праць» [7, 85]. Два роки тривала науково-просвітницька та мистецька діяльність ЧВСУ щодо пропагування духовного спадку С. Русової на ії малій батьківщині, що увінчалася прийняттям урядової Постанови № 796-93-п «Про присвоєння імені Софії Русової Олешнянській середній загальноосвітній школі Ріпкинського району» від 23 вересня 1993 р.

У 1996 р. у міжнародній пресі було оголошено про ініціативу ЧВСУ «поставити пам'ятник Софії Русовій, котра своїм просвітительським піклуванням про українську дітвору може послужити моделлю матері, що дбає про розвиток своїх дітей» $[2,13]$. У 2016 р. ЧВСУ встановив погруддя С. Русової (скульптор П. Пікуль) на подвір'ї Ріпкінської гімназії, що названа ії ім'ям.

ЧВСУ урочисто відзначав усі пам'ятні дати, пов'язані з С. Русовою. Протягом 1996-2014 pp. літературно-музичні програми, створені Р. Решетнюк за книгою С. Русової «Мої спомини», не сходили зі сцени філармонії. Вони демонструвалися у населених пунктах Чернігівщини, пов'язаних із С. Русовою, усіх школах Чернігова, де Р. Решетнюк розповідала про життєтворчість діячки, дарувала бібліотекам, вчителям і вихователям примірники «Теорії і практики дошкільного виховання» С. Русової.

Пропагування ідей С. Русової відбувалося на наукових зібраннях, ініційованих ЧВСУ. Так, у 1992 р. чернігівські союзянки організували науково-практичну конференцію «Українка XX сторіччя», що зібрала учасників з Чернігова, Ніжина, Остра, Прилук і Києва. На конференції прозвучали доповіді про діячів (О. Теліга, С. Русова, Г. Ващенко та ін.), донедавна заборонених до згадки. Почесними гостями конференції були голова Світової федерації українських жіночих організацій (США) О. Соколик і її заступниця Н. Даниленко. У 1993 р. ЧВСУ провів конференцію «Видатні жінки Чернігівщини», а у 1996 р. організував наукову конференцію «Спадщина Софії Русової та іiі значення в духовному й національному відродженні України». У лютому 2000 р. Р. Решетнюк доповіла про діяльність ЧВСУ з вшанування пам'яті й поширення науково-педагогічного спадку С. Русової на міжнародній науковій конференції, що відбулася у Чехії з ініціативи Т. Беднаржової - «продовжувача піонерської роботи Софії Русової у Празі» $[4,6]$. За згадкою Р. Решетнюк, «незважаючи на скруту, що оповила українську інтелігенцію, я знайшла можливість прибути у Прагу і Подєбради, і була єдиним представником України» [7, 89]. 
Практичне застосування педагогічних ідей С. Русової союзянками відбувалося у діяльності недільної школи ЧВСУ, утвореної у 1994 р. До праці з дітьми у недільній школі були залучені священники УПЦ (КП) для навчання Слова Божого; заняття з народознавства, етики, української мови і літератури проводила заступниця голови ЧВСУ, заслужений учитель України О. Гребницька. За їі згадкою, «вчили з дітьми колядки, щедрівки, вивчали звичаї українського народу за книгою Олекси Воропая, долучалися до ментально властивих українській нації морально-етичних норм поведінки, відкривали для себе невідомі сторінки української поезії, історії, національної культури» [7, 73].

Висновки. 3 вищенаведеного можна констатувати, що діяльність ЧВСУ здійснила вагомий внесок у національно-культурне відродження Чернігівщини: союзянки доклали зусиль до відновлення присутності у регіоні УПЦ КП; сприяли відродженню традицій відзначення народно-звичаєвих та християнських свят. Обрядовий гурт ЧВСУ щорічно відтворював народні обрядові дійства календарного циклу на загальноміському рівні, сформувавши підгрунтя адекватного сприйняття чернігівською публікою творчості філармонійного Ансамблю пісні і танцю «Сіверські клейноди», що почав діяти як професійний репрезентант регіональної обрядовості з 2002 р. Діяльність Обрядового гурту ЧВСУ стала чинником активізації міського фестивального руху аматорського спрямування: фестиваль Різдвяних вертепів, фестиваль «Коза», обласний фестиваль «Іван Купала на Голубих озерах» тощо.

Силами ЧВСУ до культурно-освітнього простору Чернігівщини було повернуто ім'я і творчий спадок С. Русової: встановлено пам'ятний знак у Олешні та погруддя у Ріпках, присвоєно ім'я діячки загальноосвітнім школам у згаданих населених пунктах, засновано Чернігівську обласну премію ім. С. Русової та благодійний фонд іiі імені. Перспективи подальщого вивчення окресленої проблематики вбачаємо у дослідженні сучасного становища ЧВСУ, вивчення внеску інших громадських об'єднань у розвиток гуманітарного простору регіону.

\section{Джерела та література}

1. Bohachevska-Chomiak M. Civil Society in Oleshnia. Our Life: Journal Ukrainian National Women's League of America. 2001. November. P. 13.

2. Bohachevska-Chomiak M. Mother's Day in Chernihiv. Our Life: Journal Ukrainian National Women's League of America. 1996. October. P. 13.
3. Lindfors-Mikhalevich N. Homage to you, Native Land. Our Life: Journal Ukrainian National Women's League of America. 1992. November. P. 9-10

4. Mušinka M. Organizer of the Ukrainian women's movement in the Czech Republic. Our Life: Journal Ukrainian National Women's League of America. 2004. February. P. 6-8.

5. Panchyk Y. «Ukrainian Women's Union» in Western Ukraine between the World Wars. Our Life: Journal Ukrainian National Women's League of America. 2013. March. P. 4-5.

6. Pashko A. Recovered from the ashes. Our Life: Journal Ukrainian National Women's League of America. October. 1993. P. 8-11.

7. Бадалов О. Раїса Решетнюк: митець, просвітниця, суспільний діяч. Ніжин: Аспект-Поліграф, 2015. 140 с.

8. Боротьба за незалежність України у 1989-1992 рр.: Чернігівська крайова організачія Народного руху України за перебудову. До 20-річчя створення Народного Руху України за перебудову: Зб. документів і матеріалів / Упоряд.: С. В. Бутко, С. В. Соломаха. Чернігів: Чернігівські обереги, 2009. $432 \mathrm{c}$.

9. Даниленко Н. Роль жіночих організацій. Наукові записки Національного університету «Острозька академія». Історичні науки. 2008. Вип. 11. С. 85-89.

10. Дармограй Н. Жіночі об'єднання в Україні та їх громадсько-культурницька діяльність (90-ті роки ХX століття): автореф. дис. ... канд. іст. наук: 07.00.01. К., 1998. 15 с.

11. Довгаль Л. Організаційна діяльність «Союзу Українок Америки». Наукові записки Тернопільського державного педагогічного університету ім. В. Гнатюка. Серія «Історія». 2013. Вип. 1, ч. 2. С. 129-134.

12. Дядюк М. Політизація українського жіночого руху в Галичині: 1921-1939 роки: автореф. дис. ... канд. іст. наук: 07.00.01. Львів, 2002. 20 с.

13. Єрмак В. Гончарне коло повертає на круги своя. Хвиля Десни. 2012. 13 грудня. С. 7.

14. Куценко П. Гостювала Масляна, веселилася. Деснянська правда. 2005. 15 березня. С. 4.

15. Марчук О. Просвітницька діяльність «Союзу Українок» на Волині на початку XX століття. Психолого-педагогічні основи гуманізації навчально-виховного процесу в школі та ВНЗ: зб. наук. праць РВЦ МЕГУ ім. акад. С. Дем'янчука. 2014. № 2 (12). С. 117-124.

16. Стахневич А. Участь жінок у розбудові громадянського суспільства в Україні (90-ті рр. XX - поч. XXI ст.): історичний аспект: автореф. дис. ... канд. іст. наук: 07.00.01. Луганськ, 2004. 20 с.

17. Фрондзей Я. Жіночий рух в Україні (90-ті роки XX ст. початок XXI ст.): автореф. дис ... канд. іст. наук: 07.00.01. Черкаси, 2012. $20 \mathrm{c}$.

18. Холодний М. Столітня війна в Чернігівському варіанті. Великдень за колючим дротом. Львів: Кобзар, 2002. 283 с.

19. Ярош О. Жіночі об'єднання України як суб'єкти державотворення кінця XX століття: автореф. дис. ... канд. політ. наук: 23.00.02. Київ, 2000. 19 с.

\section{References}

1. Bohachevska-Chomiak, M. (2001). Civil Society in Oleshnia. Our Life: Journal Ukrainian National Women's League of America. 2001. November. P. 13 [in English].

2. Bohachevska-Chomiak, M. (1996). Mother's Day in Chernihiv. Our Life: Journal Ukrainian National Women's League of America. 1996. October. P. 1313 [in English].

3. Lindfors-Mikhalevich, N. (1992). Homage to you, Native Land. Our Life: Journal Ukrainian National Women's League of America. 1992. November. P. 9-10. [in English].

4. Mušinka, M. (2004). Organizer of the Ukrainian women's movement in the Czech Republic. Our Life: Journal Ukrainian 
National Women's League of America. 2004. February. P. 6-8 [in English].

5. Panchyk, Y. (2013). «Ukrainian Women's Union» in Western Ukraine between the World Wars. Our Life: Journal Ukrainian National Women's League of America. 2013. March. P. 4-5 [in English].

6. Pashko, A. (1993). Recovered from the ashes. Our Life: Journal Ukrainian National Women's League of America. October. 1993. P. 8 [in English].

7. Badalov, O. (2015). Raisa Reshetnyuk: artist, educator, public figure. Nizhyn: Aspekt-Polihraf, 2015. 140 [in English].

8. The struggle for independence of Ukraine in 1989-1992: Chernihiv regional organization of the People's Movement of Ukraine for reconstruction. To the $20^{\text {th }}$ anniversary of the creation of the People's Movement of Ukraine for reconstruction: Coll. documents and materials / Uporiad.: S. V. Butko, S. V. Solomakha. (2009). Chernihiv: Chernihivski oberehy, 2009. 432 [in Ukrainian].

9. Danylenko, N. (2008). The role of women's organizations. Scientific notes of the Ostroh Academy National University. Historical sciences. 2008. Vyp. 11. S. 85-89 [in Ukrainian].

10. Darmohrai, N. (1998). Women's associations in Ukraine and their social and cultural activities ( 90 -ies of the $20^{\text {th }}$ century) : avtoref. dys. ... kand. ist. nauk:: 07.00.01. K., 1998. 15 [in Ukrainian].

11. Dovhal, L. (2013). Organizational Activity of the Union of Ukrainian Women of America. Scientific notes of Ternopil
State Pedagogical University. V. Hnatyuk. The History Series. 2013. Vyp. 1, ch. 2. S. 129-134 [in Ukrainian].

12. Diadiuk, M. (2002). Politicization of the Ukrainian women's movement in Galicia: 1921-1939: avtoref. dys. ... kand. ist. nauk: 07.00.01. Lviv, 2002. 20 [in Ukrainian].

13. Iermak, V. (2012). The potter's circle returns to his circles. Khvylia Desny. 2012. 13 hrudnia. S. 7 [in Ukrainian].

14. Kutsenko, P. (2005). Guest of Maslyana, having fun. Desnianska pravda. 2005. 15 bereznia. S. 4 [in Ukrainian].

15. Marchuk, O. (2014). Educational activities of the Union of Ukrainians in Volyn in the early 20th century. Psychological and pedagogical bases of humanization of educational process in school and high school: collection of scientific works of RVC MEGU named after acad. S. Demianchuk. 2014. № 2 (12). S. 117-124 [in Ukrainian].

16. Stakhnevych, A. (2004). Women's participation in civil society development in Ukraine (90's of $20^{\text {th }}-$ beginning of $21^{\text {th }}$ centuries): historical aspect: avtoref. dys. ... kand. ist. nauk: 07.00.01. Luhansk, 2004. 20 [in Ukrainian].

17. Frondzei, Ya. (2012). Women's movement in Ukraine (90s of $20^{\text {th }}$ century - beginning of $21^{\text {th }}$ century): avtoref. dys ... kand. ist. nauk: 07.00.01. Cherkasy, 2012. 20 [in Ukrainian].

18. Kholodnyi, M. (2002). Centenary war in the Chernihiv variant. Easter behind barbed wire. Lviv: Kobzar, 2002. 283 [in Ukrainian].

19. Iarosh, O. (2000). Women's Unions of Ukraine as Subjects of State-Building at the end of the 20th century: avtoref. dys. ... kand. polit. nauk: 23.00.02. Kyiv, 2000. 19 [in Ukrainian]. 